\title{
Article \\ Efficient Ag-Doped Perovskite Solar Cells Fabricated in Ambient Air
}

\author{
Jiabin Hao ${ }^{1, *}$, Zeming Wang ${ }^{2}$, Huiying Hao ${ }^{3, *}$, Guanlei Wang ${ }^{1}$, Hongcheng Gao ${ }^{1}$, Jianyu Wang ${ }^{1}$, Bing Pan ${ }^{1}$ \\ and Qiang Qi ${ }^{1}$
}

check for updates

Citation: Hao, J.; Wang, Z.; Hao, H.; Wang, G.; Gao, H.; Wang, J.; Pan, B.; Qi, Q. Efficient Ag-Doped Perovskite Solar Cells Fabricated in Ambient Air. Crystals 2021, 11, 1521. https:// doi.org/10.3390/cryst11121521

Academic Editors: M. Ajmal Khan and Saripally Sudhaker Reddy

Received: 2 November 2021

Accepted: 1 December 2021

Published: 6 December 2021

Publisher's Note: MDPI stays neutral with regard to jurisdictional claims in published maps and institutional affiliations.

Copyright: (C) 2021 by the authors. Licensee MDPI, Basel, Switzerland. This article is an open access article distributed under the terms and conditions of the Creative Commons Attribution (CC BY) license (https:// creativecommons.org/licenses/by/ $4.0 /)$.
1 Department of Chemical Engineering, Chengde Petroleum College, Chengde 067000, China; wangguanlei@126.com (G.W.); gaohc_85@163.com (H.G.); polymer168@126.com (J.W.); taode_JW@163.com (B.P.); qiqiang7911@163.com (Q.Q.)

2 Hebei Tourism Vocational College, Chengde 067000, China; Wangzm_89@126.com

3 School of Science, China University of Geosciences, Beijing 100083, China

* Correspondence: jiajooy@163.com (J.H.); huiyinghaol@cugb.edu.cn (H.H.)

\begin{abstract}
So far, it is still a great challenge to prepare high efficiency organic-inorganic perovskite solar cells in ambient air. Specifically, moisture is easily combined with the perovskite material during the spin-coating process, which result in porous perovskite films with poor surface morphology. In this study, we investigated crystalline Ag-doped perovskite films by a one-step spin-coating method in air with $30-40 \%$ relative humidity $(\mathrm{RH})$, in which ethyl acetate (EA) was used as antisolvent can absorb moisture in air to reduced nucleation density. More significantly, EA is a feasible and environmentally friendly solvent to replace highly toxic solvent. Moreover, $1.0 \%$ Ag-doped device shows a highest power conversion efficiency (PCE) of $14.36 \%$. The improved performance is not only ascribed to the superior $\mathrm{CH}_{3} \mathrm{NH}_{3} \mathrm{PbI}_{3}$ film with high crystallinity but to the versatile tunability of energy band structure.
\end{abstract}

Keywords: perovskite solar cells; Ag-doped; 30-40\% RH; ethyl acetate (EA)

\section{Introduction}

Recently, worldwide efforts have been made to continuously improve the power conversion efficiency (PCE) of perovskite solar cells (PSCs) [1]. High performance of PSCs can be attributed to excellent photoelectric property of high absorption coefficient, tunable band gap, and long charge carrier diffusion length [2-4]. $\mathrm{CH}_{3} \mathrm{NH}_{3} \mathrm{PbI}_{3}\left(\mathrm{MAPbI}_{3}\right)$ is a typical perovskite material in which the electronic band structure is mainly determined by the $\mathrm{Pb}$ and $\mathrm{I}$ and the monovalent cation $\mathrm{MA}^{+}$which mainly regulates the lattice constants of perovskite crystals $[5,6]$. It is inevitable that the composition of perovskite would affect optoelectronic properties including the light absorption, carrier transport property and the band gap. It has shown that tuning the energy band structure and properties of perovskite materials through a partial substitution of the divalent metal, such as Sn, Ca, or Ba [7-9], the monovalent cation (e.g., K, Na, Cu) or trivalent cation such as Bi or In for Pb [10-13]. However, in the cationic doping behavior of $\mathrm{MAPbI}_{3}$, there are few reports of Ag-doped perovskite $[14,15]$. It has been found that $\mathrm{Ag}$-doped perovskite material $\mathrm{MAPb}_{1-\mathrm{x}} \mathrm{Ag}_{\mathrm{x}} \mathrm{I}_{3}$ has a p-type conductive behavior by using the first-principles calculations [16].

Despite numerous studies for high efficiency of PSCs, the fabrication process of the perovskite layer and devices storage conditions is very sensitive to moisture, oxygen, and another environmental factor. So far, most of the research on high efficiency perovskite devices was obtained under the relatively low oxygen and moisture in gloveboxes [17-20]. In fact, it needs to be solved that the fabrication and storage of perovskite solar cells in air for further commercial production and application. Therefore, researchers have been trying to fabricate perovskite films and devices in ambient air. Tan et al. reported a simplified close space sublimation (CSS) deposition to grow a high quality $\mathrm{MAPbI}_{3}$ thin film in a 
low-vacuum and even non-vacuum oven [21]. Yu et al. found the modest crystal growth under high humid condition of 70\% RH can benefit the formation of perovskite films with high crystallinity and low crystal defect density [22]. Recently, the green solvents of ethyl acetate (EA) or methyl acetate (MA) was employed as antisolvent during one-step deposition in air to fabricate perovskite solar cells [23,24]. Singh et al. demonstrated that EA was used as an antisolvent to obtain the mixed cation Cs/MA/FA perovskite film with high crystallinity and the perovskite device with high efficiency of 19.8\% [23].

So far, it is difficult to synthesize high-efficiency perovskite batteries in the air by simple and feasible methods. There is no research report on the synthesis of Ag-doped perovskite in air. Therefore, both performance improvement of devices and environmentally friendly considerations, $\mathrm{Ag}$ was attempted to partially substitute toxic $\mathrm{Pb}$ in $\mathrm{MAPbI}_{3}$ perovskite films. In this work, $\mathrm{Ag}^{+}$was chosen as the doping element to partially replace $\mathrm{Pb}^{2+}$ due to their similar ionic radii, which could improve the film morphology and crystallinity. In addition, Ag incorporation has a potential impact on tuning energy band structures of organic-inorganic perovskite materials. The green antisolvent EA was used to replace highly toxic, common solvent chlorobenzene (CB) or toluene (TL). Therefore, the Ag-doped $\mathrm{MAPbI}_{3}$ perovskite films were formed in ambient air with $30-40 \%$ relative humidity (RH). When the $\mathrm{Ag}^{+}$doping content is $1.0 \%$, the perovskite film with higher crystallinity and full surface coverage was obtained. It is found that the Fermi energy level of Ag-doped $\mathrm{MAPbI}_{3}$ material slight downshift towards the valence band edge, which improve the charge carrier transport. As a result, the Ag-doped PSCs fabricated in ambient atmosphere with a power conversion efficiency (PCE) of $14.26 \%$ is observed. We believe that this study would provide a good direction for PSCs development in ambient air.

\section{Materials and Methods}

\subsection{Materials}

The transparent conductive FTO/glass substrates with sheet resistance of $10 \Omega$ /sq was purchased from Pilkington glasses. The titanium(IV) isopropoxide (99.5\%) was supplied by Alfa Aesar Chemical Co., Ltd.(Shanghai, China); Lead(II) iodide (PbI2, 99\%) was proved by Sigma-Aldrich Co. (Shanghai, China); Silver iodide (AgI, 99.99\%), N,NDimethylformamide (DMF, 99.9\%) and chlorobenzene (99.5\%) were purchased from Aladdin Ltd. Co. All the other materials were obtained from Xi'an Polymer Light Technology Crop., including Methylammonium iodide (MAI, 99.5\%), Spiro-OMeTAD (99.5\%), Li-TFSI $(99 \%)$ and TBP $(96 \%)$.

\subsection{Device Fabrication}

FTO/glass substrates were cleaned in acetone, isopropanol and ethanol, deionized water sequentially for $15 \mathrm{~min}$ and then dried under air stream. The synthesis process of the Ag-doped perovskite solar cells can refer to the reported method [25]. The compact $\mathrm{TiO}_{2}$ layer was prepared by spin-coating the precursor consisting of $100 \mu \mathrm{L}$ titanium (IV) isopropoxide, $2.5 \mathrm{~mL}$ ethanol and $20 \mu \mathrm{L}$ dilute hydrochloric acid at $3000 \mathrm{rpm} / 30 \mathrm{~s}$ and subsequently sintering at $500{ }^{\circ} \mathrm{C}$ for $30 \mathrm{~min}$. The substrates were further treated with $40 \mathrm{mM} \mathrm{TiCl}_{4}$ aqueous solution at $70{ }^{\circ} \mathrm{C}$ for $30 \mathrm{~min}$ in the oven, and then cleaned with deionized water to sinter at $500{ }^{\circ} \mathrm{C}$ for $30 \mathrm{~min}$. The mesoporous $\mathrm{TiO}_{2}$ layer was obtained by spin-coating the precursor consisting of a $\mathrm{TiO}_{2}$ paste diluted by ethanol of $1: 7$ weight ratio at $4500 \mathrm{rpm} / 40 \mathrm{~s}$ and then baked at $500{ }^{\circ} \mathrm{C}$ for $30 \mathrm{~min}$. After cooling to room temperature, the $\mathrm{TiO}_{2}$ films were immersed into $20 \mathrm{mM} \mathrm{TiCl}_{4}$ solution at $70{ }^{\circ} \mathrm{C}$ for $30 \mathrm{~min}$ and then heated treated at $500{ }^{\circ} \mathrm{C}$ for $30 \mathrm{~min}$. To obtain the Ag-doped perovskite materials, the AgI, $\mathrm{CH}_{3} \mathrm{NH}_{3} \mathrm{I}$ and $\mathrm{PbI}_{2}$ with a molar ratio of $\mathrm{x}: 1: 1-\mathrm{x}(0 \leq \mathrm{x} \leq 0.05)$ were dissolved in DMF to prepare Ag-doped perovskite precursor solution whose concentration were $0 \%, 0.5 \%, 1.0 \%, 3.0 \%$, and $5.0 \%$, respectively. The perovskite layer was obtained by one step solution technique in ambient air with $30-40 \% \mathrm{RH}$, in which the precursor solution was spin-coated onto the mesoporous $\mathrm{TiO}_{2}$ layer at $4000 \mathrm{rpm}$ for $20 \mathrm{~s}$. During the spincoating process, $100 \mu \mathrm{L}$ EA antisolvent was dripped onto the precursor film after about 
$6 \mathrm{~s}$, and then annealed at $100{ }^{\circ} \mathrm{C}$. The hole transport material consisting of $72.3 \mathrm{mg}$ spiroOMeTAD in $1 \mathrm{~mL}$ chlorobenzene with additives consisting of $17.5 \mu \mathrm{L} \mathrm{Li}$-TFSI/acetonitrile $(520 \mathrm{mg} / \mathrm{mL}), 28.8 \mu \mathrm{L}$ of TBP was spin-coated at $2000 \mathrm{rpm}$ for $40 \mathrm{~s}$. Ag electrode with $100 \mathrm{~nm}$ was deposited on the top of the device using thermal evaporation. Finally, the Ag-doped perovskite solar cells were successfully obtained. The active area was $0.1 \mathrm{~cm}^{2}$.

\subsection{Characterization Techniques}

$\mathrm{X}$-ray diffraction (XRD) test were carried out by an X-ray power diffractometer (D8 Advance, Bruckers AXS, $\mathrm{Cu}$ Ka radiation). The morphological properties of the samples were characterized by the S-4800 scanning electron microscope (SEM). X-ray photoelectron spectroscopy (XPS) and ultraviolet photoelectron spectroscopy (UPS) were carried out by ESCALAB 250Xi (ThermoFisher Scientific). Photocurrent density-voltage (J-V) curves of solar cells were measured with a Keithley 2400 source meter under the simulated AM 1.5G illumination at a calibrated intensity of $100 \mathrm{~mW} / \mathrm{cm}^{2}$ by a Class AAA solar simulator at room temperature in the air, and the scanning direction is from open circuit at $1.2 \mathrm{~V}$ to short circuit at $0 \mathrm{~V}$ with a scan rate of $100 \mathrm{mV} / \mathrm{s}$. Steady-state photo-luminescence (PL) spectroscopy was measured with an excitation wavelength of $510 \mathrm{~nm}$. The light absorption spectra were recorded on a UV-vis-NIR spectrophotometer (Cary 5000).

\section{Results and Discussion}

Here, $\mathrm{Ag}^{+}$is chosen to partially substitute $\mathrm{Pb}^{2+}$ because its ionic radius of $12.9 \AA$ is close to that of $\mathrm{Pb}^{2+}(13.3 \AA)$ to tune the electrical properties and energy band structure of $\mathrm{MAPbI}_{3}$ perovskite material [15]. XRD patterns of perovskite films with Ag-doped concentration from $0 \%$ (pristine) to $5.0 \%$ are shown in Figure 1. The three strong scattering peaks located at $2 \theta$ values of $14.20^{\circ}, 28.51^{\circ}$, and $31.92^{\circ}$ can be identified with reflections form (110), (220), and (310) planes, suggesting that the $\mathrm{MAPbI}_{3}$ films with tetragonal crystal structure were obtained in this study. In addition, an increase in diffraction intensity of Ag-doped $\mathrm{MAPbI}_{3}$ materials can be observed in the patterns. Specially, significant changes manifested in full width of half maximum (FWHM) of the strongest (110) diffraction peaks, in which the FWHM value of $1.0 \% \mathrm{Ag}$ concentration is 0.105 lower than that of pristine sample (0.124). The results indicate that the crystallinity is enhanced by appropriate Ag doping amount.

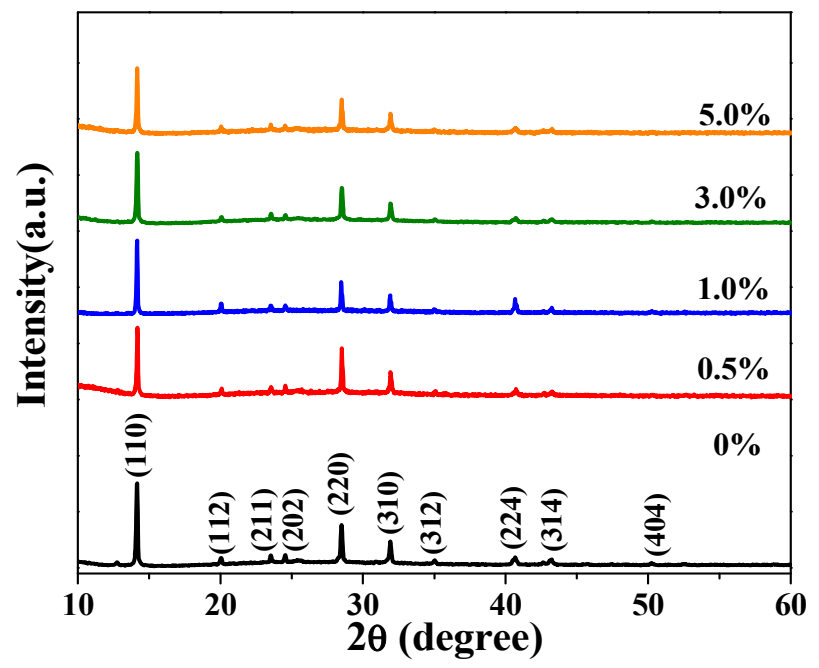

Figure 1. XRD patterns of Ag-doped perovskite films in which Ag incorporation is $0 \%, 0.5 \%, 1.0 \%$, $3.0 \%$, and $5.0 \%$.

The SEM images of perovskite films is shown in Figure 2a-e. It is found that the roughness of Ag-doped $\mathrm{MAPbI}_{3}$ thin films obtained in air is slightly higher, which may be ascribed to the grain-merging tendency induced by humidity annealing conditions [26,27]. 
We calculated the grain size of $\mathrm{Ag}$-doped $\mathrm{MAPbI}_{3}$ materials and displayed the distribution statistically in Figure S1 according to the SEM images. It shows the grain size centrally of Ag-doped $\mathrm{MAPbI}_{3}$ thin films distributes at $200 \mathrm{~nm}$ that is larger than that of pristine sample. The $1.0 \%$ Ag-doped $\mathrm{MAPbI}_{3}$ thin film exhibits a uniform surface morphology and high crystalline quality, which occurs possibly because EA can absorb the water in air rather than reacted with precursor solution. Therefore, the reduced nucleation density makes it possible for more solute to merge with formed nucleus to generate bigger grains in air with high humidity.
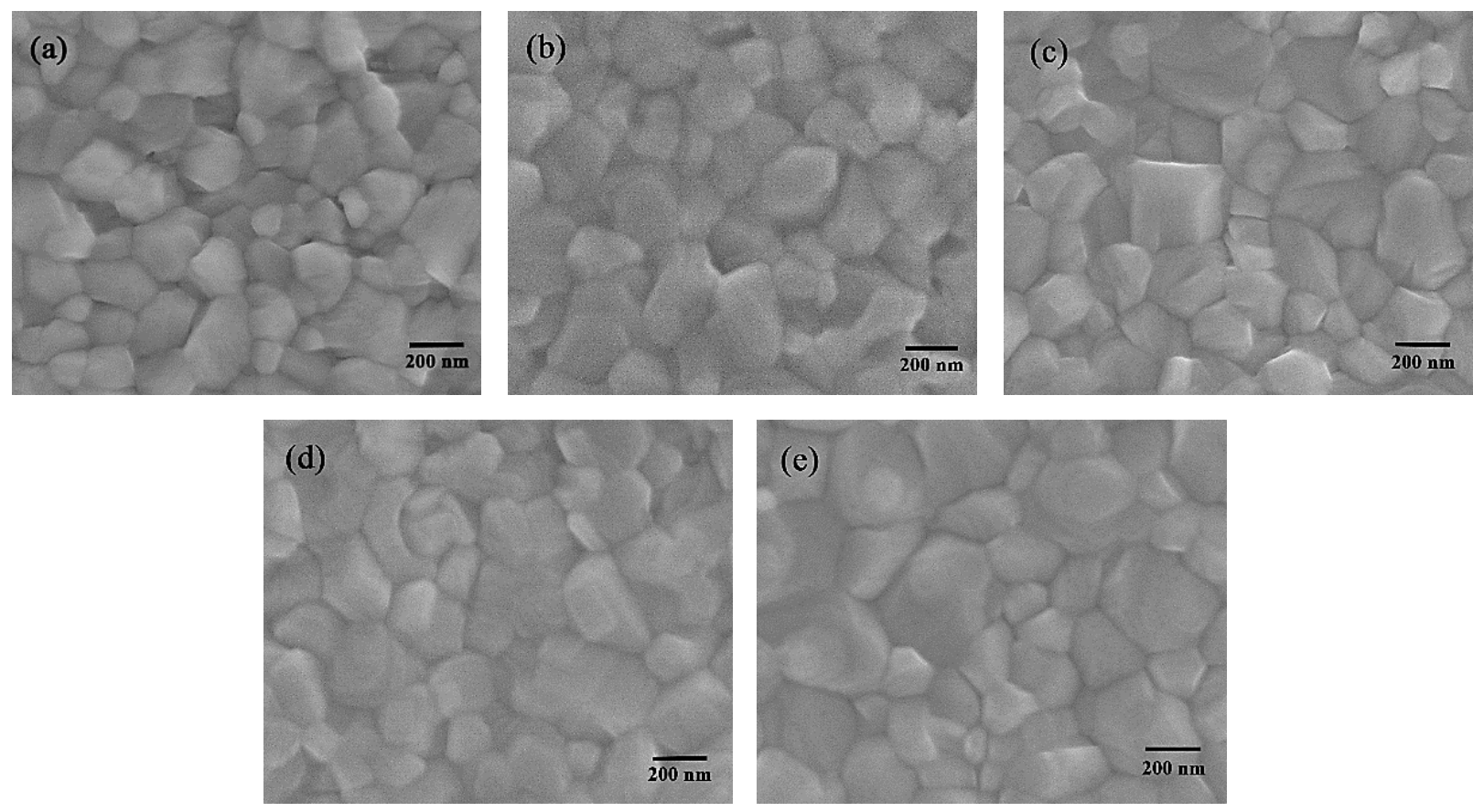

Figure 2. Top-view SEM images of perovskite films with different Ag incorporation: (a) $0 \%$, (b) $0.5 \%$, (c) $1.0 \%$, (d) $3.0 \%$, and (e) $5.0 \%$.

In order to study the effect of Ag doping on the optical properties of $\mathrm{MAPbI}_{3}$ films, the UV-visible absorption spectral of perovskite thin films shown in Figure 3a. All samples have similar absorption curves in the range from $400 \mathrm{~nm}$ to $800 \mathrm{~nm}$. The absorption intensity of Ag-doped $\mathrm{MAPbI}_{3}$ samples is obviously stronger than that of undoped sample between $400 \mathrm{~nm}$ to $550 \mathrm{~nm}$, suggesting that Ag incorporation increases light harvesting capability. Meanwhile, the Tauc plots was inserted in the UV-IR spectra to estimate the band gap of all samples, in which the band gap of samples with $0,0.5 \%, 1.0 \%, 3.0 \%$, and $5.0 \% \mathrm{Ag}$ doping concentration is $1.588,1.601,1.596,1.588$, and $1.589 \mathrm{eV}$, respectively. This indicates the band gap of perovskite materials increased a little than that of pristine $\mathrm{MAPbI}_{3}$ material. Furthermore, the steady-state PL spectra of perovskite films deposited on the hole transport layer are displayed in Figure 3b. It shows all PL peaks can be observed at around $766 \mathrm{~nm}$. It is found that the PL peak intensity of Ag-doped perovskite films/spiro-OMeTAD first decreases and then increases with the Ag-doped amount. In addition, the emission peaks of Ag-doped perovskite films with $\mathrm{Ag}$ corporation concentration of $0.5 \%$ and $1.0 \%$ have a slightly blue shifts, which is consistent with the results of the UV-visible absorption spectral. Another phenomenon can be addressed is that the intensity of the emission peak of $1.0 \%$ $\mathrm{Ag}$ doping $\mathrm{MAPbI}_{3}$ material was reduced sharply, suggesting that the better excitation separation at the Ag-doped $\mathrm{MAPbI}_{3}$ layer/the hole transport layer interface [28], which would be improve the photovoltaic conversion performance of perovskite solar cells. 

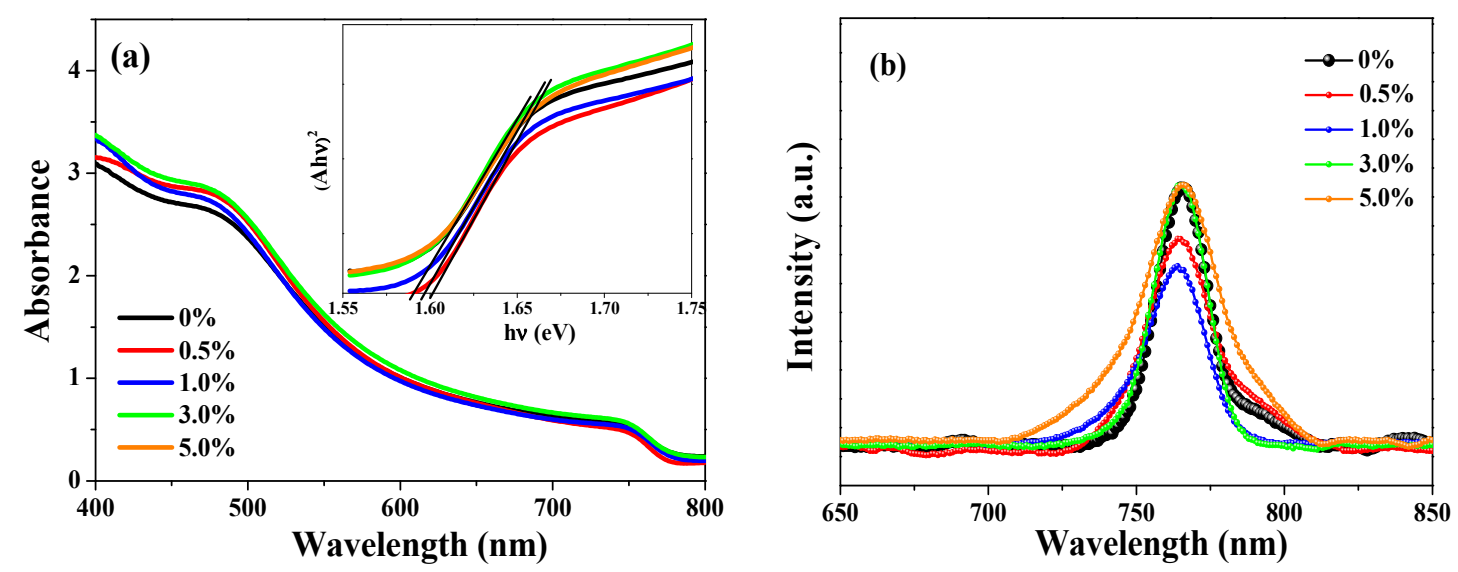

Figure 3. (a). The UV-visible absorption spectral of Ag-doped perovskite films, the insert image is Tauc plot curves; (b) Steady-state PL spectra of Ag-doped perovskite films deposited on spiro-OMeTAD.

Considering the influence on the energy band structure of $\mathrm{MAPbI}_{3}$ perovskite material after doping $\mathrm{Ag}^{+}$, as well as the polarity, the ultraviolet photoelectron spectra (UPS) was used to characterize the change and the results are shown in Figure 4 and the Fermi energy level position has been calibrated. The valence band edge of 1.0\% Ag-doped $\mathrm{MAPbI}_{3}$ material is closer to the Fermi energy level position than that of pristine sample. The result indicates that $\mathrm{Ag}$ doping in perovskite film would lead to the polarity transition from the initial n-type character to a p-type character [29,30], which will enhance the charge transport property of photogenerated holes at the interface. In order to detect the chemical composition distribution and electronic structure of perovskite films, the X-ray spectroscopy (XPS) was carrier out to obtain relative element information of Agdoped $\mathrm{MAPbI}_{3}$ materials prepared in air. The $\mathrm{C}, \mathrm{N}, \mathrm{Pb}$, and I elements can be successfully observed in both similar XPS spectra shown in Figure S2a,b, indicating the formation of $\mathrm{MAPbI}_{3}$ films. In the high-resolution XPS spectrum, the presence of the Ag 3d5/2 and Ag $3 \mathrm{~d} 5 / 2$ can be confirmed in the Ag-doped perovskite film.
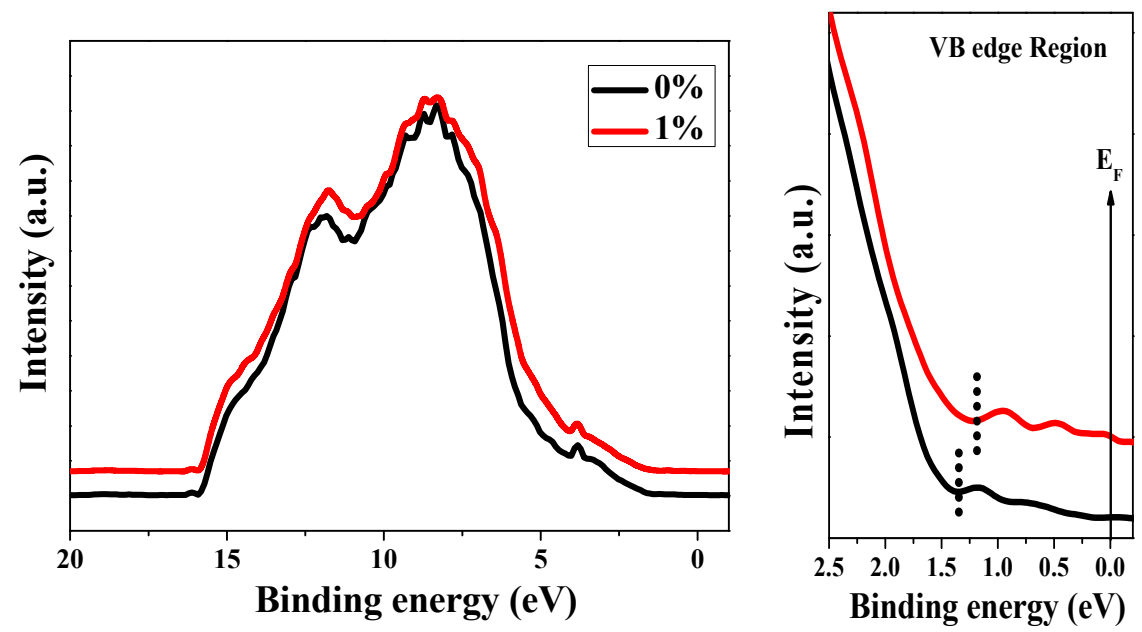

Figure 4. The UPS spectra of pristine $\mathrm{MAPbI}_{3}$ film and 1.0\% Ag-doped perovskite film.

To assess the influence of $\mathrm{Ag}$ doping behavior on the trap states of perovskite materials, we fabricated capacitor-like devices of FTO/perovskite with different Ag doping concentration/Au based on space-charge-limited current (SCLC) method to evaluate the trap density shown in Figure 5. The I-V curves plotted on a double log were acquired in the dark, which can be divided into two parts: the ohmic region where the current increased linearly with increasing voltage in the low bias voltage, and the trap-filled limit region where current increased nonlinearly in the high bias voltage [31,32]. To evaluate the 
trap-state density $\left(\mathrm{n}_{\mathrm{t}}\right)$ in the Ag-doped $\mathrm{MAPbI}_{3}$ samples, the trap filled limit voltage $\left(V_{T F L}\right)$ is the transition point from the ohmic region to the trap-filled limit region, which can be obtained using the following equation [33,34]: This is example 1 of an equation:

$$
V_{T F L}=\frac{e \mathrm{n}_{\mathrm{t}} \mathrm{L}^{2}}{2 \varepsilon \varepsilon 0}
$$

where $e$ is the elementary charge of the electron, $\mathrm{L}$ represents the thickness of the perovskite films, $\varepsilon$ is the relative dielectric constant of perovskite films and is the vacuum permittivity. The $V_{\text {TFL }}$ values of devices with $\mathrm{Ag}$ corporation concentration from 0 to $5.0 \%$ were 0.874 , $0.686,0.691,0.915$, and $0.964 \mathrm{~V}$. From the Equation (1), the trap-state density $\mathrm{n}_{\mathrm{t}}$ of Ag-doped samples with $0,0.5 \%, 1.0 \%, 3.0 \%$, and $5.0 \%$ is calculated to be $2.52 \times 10^{16}, 1.98 \times 10^{16}$, $2.00 \times 10^{16}, 2.64 \times 10^{16}$, and $2.78 \times 10^{16} \mathrm{~cm}^{-3}$. It shows the perovskite films with $3.0 \%$ and $5.0 \% \mathrm{Ag}$ doping have similar defect states to that of the undoped $\mathrm{MAPbI}_{3}$ sample. However, the $0.5 \%$ and $1.0 \% \mathrm{Ag}$ doping can decrease the trap-state density of perovskite materials. Therefore, the appropriate Ag doping concentration can passivate the defect of $\mathrm{MAPbI}_{3}$ films, which improve the performance of perovskite solar cells.

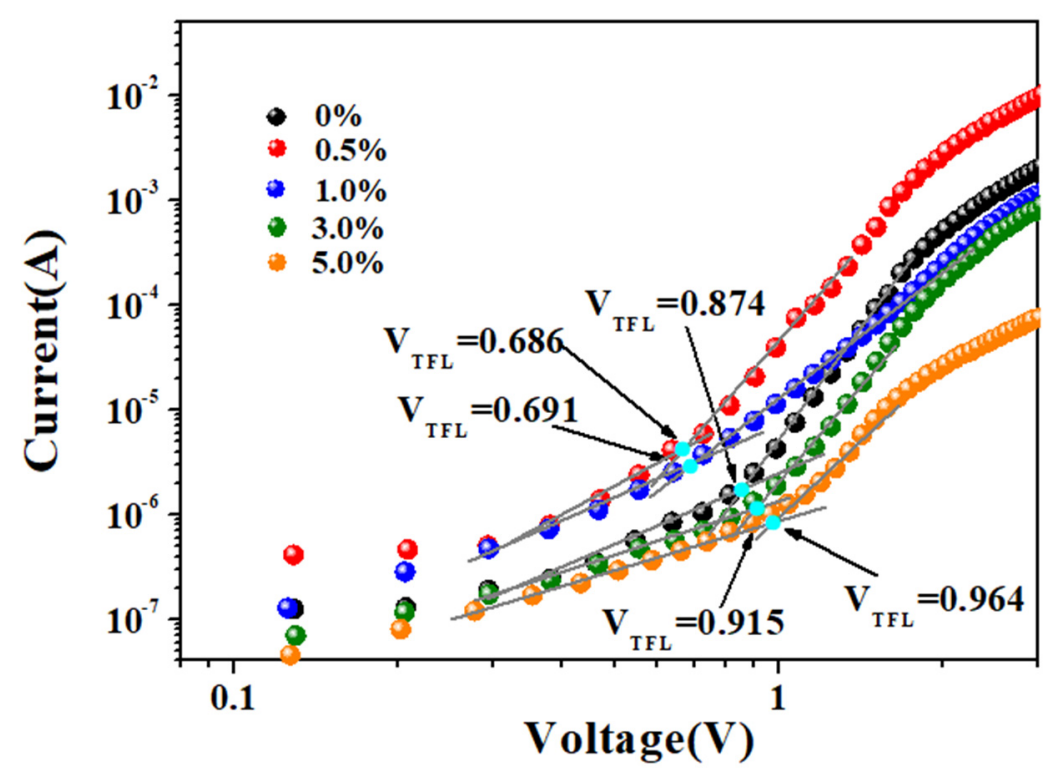

Figure 5. Current density-voltage characteristics of devices with FTO/perovskite/Au configuration utilized for estimating the defect density in perovskite films with Ag corporation concentration from 0 to $5.0 \%$.

Figure 6 shows the photocurrent density-voltage (J-V) characteristic curves of perovskite solar cells based on the $\mathrm{FTO} / \mathrm{c}-\mathrm{TiO}_{2} / \mathrm{m}-\mathrm{TiO}_{2} /$ perovskite $/ \mathrm{Ag}$. It is found that the $\mathrm{J}-\mathrm{V}$ performance of Ag-doped perovskite solar cells first increases and then decreases with the Ag-doped amount. The undoped perovskite device has a power conversion efficiency (PCE) of $11.40 \%$ with an open circuit voltage $\left(\mathrm{V}_{\mathrm{OC}}\right)$ of $0.973 \mathrm{~V}$, a short-circuit current density (JSC) of $21.08 \mathrm{~mA} / \mathrm{cm}^{2}$ and a fill factor (FF) of 0.556 . On the contrary, the $1.0 \%$ Ag-doped perovskite device exhibited a highest PCE of $14.26 \%$ with a $\mathrm{V}_{\mathrm{OC}}$ of $1.035 \mathrm{~V}$, a JSC of $22.08 \mathrm{~mA} / \mathrm{cm}^{2}$ and an FF of 0.624 in Table 1. Such high device performance should be ascribed to the compact and uniform perovskite film, the decrease in trap-state density and increase in charge extraction capacity of $1.0 \%$ Ag-doped perovskite device. When the Ag doping concentration increased to $3.0 \%$ and $5.0 \%$, the PCE of devices decreased to $11.12 \%$ and $10.74 \%$, which may be due to the carrier recombination in the bulk of perovskite film or at the perovskite layer/charge transport layer interface. In addition, good device repeatability of Ag-doped perovskite solar cells prepared in air with $30-40 \% \mathrm{RH}$ can be shown in Figure S3. J-V hysteresis phenomenon is possibly to the polarization at the interface, motion of ions, the change of electronic properties between the contact 
interfaces and ferroelectric effect. The 1.0\% Ag-doped perovskite solar cell (RS-A) with a test of backward direction exhibited a highest PCE of $11.68 \%$ with a $\mathrm{V}_{\mathrm{OC}}$ of $0.976 \mathrm{~V}$, a JS of $19.88 \mathrm{~mA} / \mathrm{cm}^{2}$ and an FF of 0.602 in Figure S4. The Ag-doped perovskite solar cell (FS-A) with a test of forward direction exhibited a highest PCE of $10.68 \%$ with a $\mathrm{V}_{\mathrm{OC}}$ of $0.935 \mathrm{~V}$, a JSC of $19.87 \mathrm{~mA} / \mathrm{cm}^{2}$ and an FF of 0.575 in Table S1. However, the pristine perovskite device shows a PCE (RS-P) of $9.10 \%$ and a PCE (FS-P) of 7.25\%. Benefited from the tuned band structure and reduced surface defect, the $\mathrm{V}_{\mathrm{OC}}$ was improved from 0.935 to $0.976 \mathrm{~V}$. The increasing of FF mainly was ascribed to less recombination in the Ag-doped perovskite solar cell. Based on the stability evaluation, Ag-doped device exhibits stabilized power output performance within 300s under continuous maximum point tracking test shown in Figure S5.

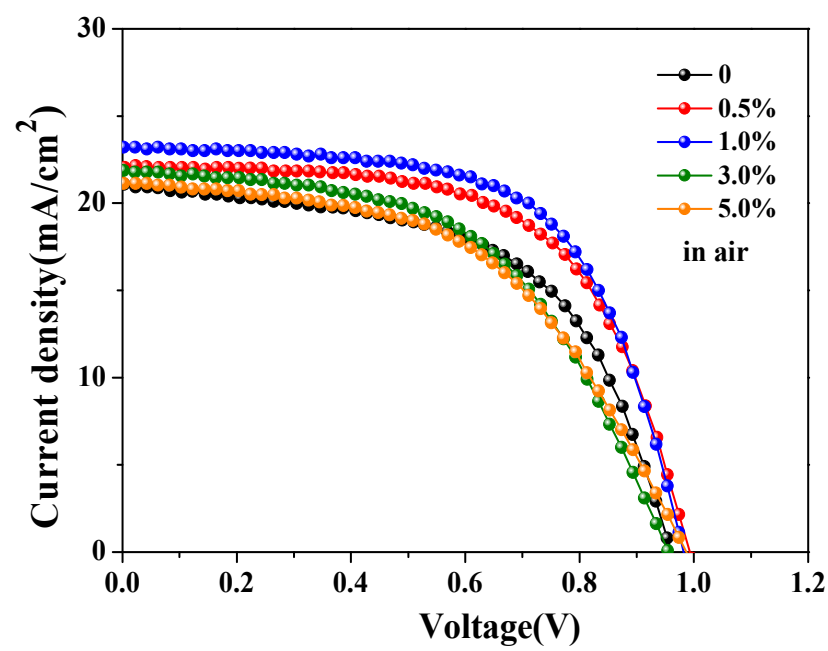

Figure 6. J-V curves of perovskite solar cells based on the $\mathrm{FTO} / \mathrm{c}-\mathrm{TiO}_{2} / \mathrm{m}-\mathrm{TiO}_{2} /$ perovskite/ spiroOMeTAD / Ag.

Table 1. Photovoltaic performances summary of the perovskite devices.

\begin{tabular}{ccccc}
\hline $\begin{array}{c}\text { Ag } \\
\text { Concentration }\end{array}$ & Voc (V) & Jsc $\left(\mathbf{m A} / \mathbf{c m}^{\mathbf{2}}\right)$ & FF & PCE (\%) \\
\hline $0 \%$ & 0.973 & 21.08 & 0.556 & 11.40 \\
$0.5 \%$ & 0.997 & 22.04 & 0.608 & 13.35 \\
$1.0 \%$ & 1.035 & 22.08 & 0.624 & 14.26 \\
$3.0 \%$ & 0.974 & 21.88 & 0.522 & 11.12 \\
$5.0 \%$ & 0.994 & 21.13 & 0.511 & 10.74 \\
\hline
\end{tabular}

\section{Conclusions}

In this study, Ag-doped perovskite films have been successfully prepared by one step deposition process in ambient air of $30-40 \% \mathrm{RH}$. We observed that the Ag-doped samples exhibit uniform surface morphology, indicating a higher crystalline quality, which possibly because EA can absorb the water in air rather than reacted with precursor solution. The $1.0 \%$ Ag-doped $\mathrm{MAPbI}_{3}$ device has a higher power conversion efficiency of $14.36 \%$, showing an improvement of $20.1 \%$ over that of the pristine device. Such an obvious performance enhancement arises not only from strongly increased charge transport efficiency but also from the lower trap state of perovskite material.

Supplementary Materials: The following are available online at https:/ / www.mdpi.com/article/10 .3390 / cryst11121521/s1, Figure S1: The statistical diagram of perovskite grain size with different Ag incorporation: (a) $0 \%$, (b) $0.5 \%$, (c) $1.0 \%$, (d) 3.0\% and (e) 5.0\%; Figure S2. The XPS spectra of (a) pristine MAPbI3 film and (b) 1.0\% Ag-doped perovskite film, and the XPS for the elements $\mathrm{C}, \mathrm{N}, \mathrm{Pb}$, $\mathrm{Ag}$ and I; Figure S3. The distribution diagram of perovskite devices with Ag doping concentration 
from 0 to $5.0 \%$ in air with $30 \%-40 \% \mathrm{RH}$, data from 20 pieces per variable condition; Figure S4. J-V curves of perovskite solar cells based on the $\mathrm{FTO} / \mathrm{c}-\mathrm{TiO}_{2} / \mathrm{m}-\mathrm{TiO}_{2} /$ perovskite/ spiro-OMeTAD / Ag; Figure S5. Steady power conversion efficiency curve of the $1.0 \%$ Ag-doped perovskite solar cell; Table S1: Table S1. Photovoltaic performances summary of the perovskite devices.

Author Contributions: Conceptualization, J.H. and H.H.; methodology, J.H. and H.H.; investigation, Z.W. and B.P.; data curation, Z.W. and B.P.; writing—original draft preparation, J.H.; writing-review and editing, H.G. and Q.Q.; supervision, G.W. and J.W.; project administration, H.H.; funding acquisition, H.H. All authors have read and agreed to the published version of the manuscript.

Funding: This work is supported by the Fundamental Research Funds for the Central Universities under Grand No. 2652017154 and 2652017163, and the National Natural Science Foundation of China under Grand No. 11404293.

Data Availability Statement: Not applicable.

Acknowledgments: We wish to express our gratitude to the members of our research team, Jiabin Hao, Zeming Wang, Huiying Hao, Guanlei Wang, Hongcheng Gao, Jianyu Wang, Bing Pan, Qiang Qi.

Conflicts of Interest: The authors declare no conflict of interest. We identify and declare any personal circumstances or interest that may be perceived as inappropriately influencing the representation or interpretation of reported research results. The funders had no role in the design of the study; in the collection, analyses, or interpretation of data; in the writing of the manuscript, or in the decision to publish the results.

\section{References}

1. Jeong, M.; Choi, I.W.; Go, E.M.; Cho, Y.; Kim, M.; Lee, B.; Jeong, S.; Jo, Y.; Choi, H.W.; Lee, J.; et al. Stable perovskite solar cells with efficiency exceeding $24.8 \%$ and $0.3-\mathrm{V}$ voltage loss. Science 2020, 369, 1615-1620. [CrossRef] [PubMed]

2. Wang, Y.; Zhang, Y.; Zhang, P.; Zhang, W. High intrinsic carrier mobility and photon absorption in the perovskite $\mathrm{CH}_{3} \mathrm{NH}_{3} \mathrm{PbI}_{3}$. Phys. Chem. Chem. Phys. 2015, 17, 11516-11520. [CrossRef]

3. Kim, S.H.; Saeed, M.A.; Lee, S.Y.; Shim, J.W. Investigating the Indoor Performance of Planar Heterojunction Based Organic Photovoltaics. IEEE J. Photovoltaics 2021, 11, 997-1003. [CrossRef]

4. Li, M.; Gao, D.; Zhang, B.; Xu, S.; Zhuang, X.; Wang, C.; Yang, L.; Ma, X.; Zheng, S.; Song, H.; et al. Multifunctional Reductive Molecular Modulator toward Efficient and Stable Perovskite Solar Cells. Sol. RRL 2021, 5, 2100320. [CrossRef]

5. Dar, M.I.; Jacopin, G.; Meloni, S.; Mattoni, A.; Arora, N.; Boziki, A.; Zakeeruddin, S.M.; Rothlisberger, U.; Grätzel, M. Origin of unusual bandgap shift and dual emission in organic-inorganic lead halide perovskites. Sci. Adv. 2016, 2, e1601156. [CrossRef] [PubMed]

6. Bi, C.; Zheng, X.; Chen, B.; Wei, H.; Huang, J. Spontaneous Passivation of Hybrid Perovskite by Sodium Ions from Glass Substrates: Mysterious Enhancement of Device Efficiency Revealed. ACS Energy Lett. 2017, 2, 1400-1406. [CrossRef]

7. Li, Y.; Sun, W.; Yan, W.; Ye, S.; Rao, H.; Peng, H.; Zhao, Z.; Bian, Z.; Liu, Z.; Zhou, H.; et al. 50\% Sn-Based Planar Perovskite Solar Cell with Power Conversion Efficiency up to 13.6\%. Adv. Energy Mater. 2016, 6, 1601353. [CrossRef]

8. Navas, J.; Sánchez-Coronilla, A.; Gallardo, J.J.; Hernández, N.C.; Pinero, J.C.; Alcántara, R.; Fernández-Lorenzo, C.; De los Santos, D.M.; Aguilar, T.; Martín-Calleja, J. New insights into organic-inorganic hybrid perovskite $\mathrm{CH}_{3} \mathrm{NH}_{3} \mathrm{PbI}_{3}$ nanoparticles. An experimental and theoretical study of doping in $\mathrm{Pb}^{2+}$ sites with $\mathrm{Sn}^{2+}, \mathrm{Sr}^{2+}, \mathrm{Cd}^{2+}$ and $\mathrm{Ca}^{2+}$. Nanoscale 2015, 7, 6216-6229. [CrossRef] [PubMed]

9. Zhang, H.; Shang, M.-H.; Zheng, X.; Zeng, Z.; Chen, R.; Zhang, Y.; Zhu, Y. Ba ${ }^{2+}$ Doped $\mathrm{CH}_{3} \mathrm{NH}_{3} \mathrm{PbI}_{3}$ to Tune the Energy State and Improve the Performance of Perovskite Solar Cells. Electrochimica Acta 2017, 254, 165-171. [CrossRef]

10. Jahandar, M.; Heo, J.H.; Song, C.E.; Kong, K.; Shin, W.S.; Lee, J.C.; Im, S.H.; Moon, S.J. Highly efficient metal halide substituted $\mathrm{CH}_{3} \mathrm{NH}_{3} \mathrm{I}\left(\mathrm{PbI}_{2}\right) 1-\mathrm{X}\left(\mathrm{CuBr}_{2}\right) \mathrm{X}$ planar perovskite solar cells. Nano Energy 2016, 27, 330-339. [CrossRef]

11. Zhao, W.; Yao, Z.; Yu, F.; Yang, D.; Liu, S. Alkali Metal Doping for Improved $\mathrm{CH}_{3} \mathrm{NH}_{3} \mathrm{PbI}_{3}$ Perovskite Solar Cells. Adv. Sci. 2017, 5, 1700131. [CrossRef]

12. Nayak, P.K.; Sendner, M.; Wenger, B.; Wang, Z.; Sharma, K.; Ramadan, A.J.; Lovrinčić, R.; Pucci, A.; Madhu, P.K.; Snaith, H.J Impact of $\mathrm{Bi}^{3+}$ Heterovalent Doping in Organic-Inorganic Metal Halide Perovskite Crystals. J. Am. Chem. Soc. 2018, 140, 574-577. [CrossRef]

13. Abdelhady, A.L.; Saidaminov, M.I.; Murali, B.; Adinolfi, V.; Voznyy, O.; Katsiev, K.; Alarousu, E.; Comin, R.; Dursun, I.; Sinatra, L.; et al. Heterovalent Dopant Incorporation for Bandgap and Type Engineering of Perovskite Crystals. J. Phys. Chem. Lett. 2016, 7, 295-301. [CrossRef]

14. Shahbazi, S.; Tsai, C.-M.; Narra, S.; Wang, C.-Y.; Shiu, H.-S.; Afshar, S.; Taghavinia, N.; Diau, E.W.-G. Ag Doping of Organometal Lead Halide Perovskites: Morphology Modification and p-Type Character. J. Phys. Chem. C 2017, 121, 3673-3679. [CrossRef]

15. Abdi-Jalebi, M.; Pazoki, M.; Philippe, B.; Dar, M.I.; Alsari, M.; Sadhanala, A.; Divitini, G.; Imani, R.; Lilliu, S.; Kullgren, J.; et al. Dedoping of Lead Halide Perovskites Incorporating Monovalent Cations. ACS Nano 2018, 12, 7301-7311. [CrossRef] [PubMed] 
16. Si, F.J.; Tang, F.L.; Xue, H.T.; Liu, J.B. Electronic and optical properties of $\mathrm{CH}_{3} \mathrm{NH}_{3} \mathrm{PbPb}_{1}$-xAgxI from the first-principles calculations. J. Renew. Sustain. Energy 2018, 10, 033504. [CrossRef]

17. Jeon, N.J.; Noh, J.H.; Yang, W.S.; Kim, Y.C.; Ryu, S.; Seo, J.; Seok, S.I. Compositional engineering of perovskite materials for high-performance solar cells. Nature 2015, 517, 476-480. [CrossRef] [PubMed]

18. Saliba, M.; Matsui, T.; Domanski, K.; Seo, J.-Y.; Ummadisingu, A.; Zakeeruddin, S.M.; Correa-Baena, J.-P.; Tress, W.R.; Abate, A.; Hagfeldt, A.; et al. Incorporation of rubidium cations into perovskite solar cells improves photovoltaic performance. Science 2016, 354, 206-209. [CrossRef] [PubMed]

19. Yang, W.S.; Park, B.-W.; Jung, E.H.; Jeon, N.J.; Kim, Y.C.; Lee, D.U.; Shin, S.S.; Seo, J.; Kim, E.K.; Noh, J.H.; et al. Iodide management in formamidinium-lead-halide-based perovskite layers for efficient solar cells. Science 2017, 356, 1376-1379. [CrossRef]

20. Jiang, Q.; Zhao, Y.; Zhang, X.W.; Yang, X.L.; Chen, Y.; Chu, Z.; Ye, Q.F.; Li, X.X.; Yin, Z.G.; You, J.B. Surface passivation of perovskite film for efficient solar cells. Nat. Photonics 2019, 1, 460-466. [CrossRef]

21. Guo, Q.; Li, C.; Qiao, W.; Ma, S.; Wang, F.; Zhang, B.; Hu, L.; Dai, S.; Tan, Z. The growth of a $\mathrm{CH}_{3} \mathrm{NH}_{3} \mathrm{PbI}_{3}$ thin film using simplified close space sublimation for efficient and large dimensional perovskite solar cells. Energy Environ. Sci. 2016, 9, 1486-1494. [CrossRef]

22. Gao, H.; Bao, C.; Li, F.; Yu, T.; Yang, J.; Zhu, W.; Zhou, X.; Fu, G.; Zou, Z. Nucleation and Crystal Growth of Organic-Inorganic Lead Halide Perovskites under Different Relative Humidity. ACS Appl. Mater. Interfaces 2015, 7, 9110-9117. [CrossRef]

23. Singh, T.; Miyasaka, T. Stabilizing the Efficiency Beyond $20 \%$ with a Mixed Cation Perovskite Solar Cell Fabricated in Ambient Air under Controlled Humidity. Adv. Energy Mater. 2017, 8, 1700677. [CrossRef]

24. Yang, F.; Kapil, G.; Zhang, P.; Hu, Z.; Kamarudin, M.A.; Ma, T.; Hayase, S. Dependence of Acetate-Based Antisolvents for High Humidity Fabrication of $\mathrm{CH}_{3} \mathrm{NH}_{3} \mathrm{PbI}_{3}$ Perovskite Devices in Ambient Atmosphere. ACS Appl. Mater. Interfaces 2018, 10, 16482-16489. [CrossRef] [PubMed]

25. Hao, J.; Hao, H.; Li, J.; Shi, L.; Zhong, T.; Zhang, C.; Dong, J.; Xing, J.; Liu, H.; Zhang, Z. Light Trapping Effect in Perovskite Solar Cells by the Addition of Ag Nanoparticles, Using Textured Substrates. Nanomaterials 2018, 8, 815. [CrossRef]

26. You, J.; Yang, Y.; Hong, Z.; Song, T.-B.; Meng, L.; Liu, Y.; Jiang, C.; Zhou, H.; Chang, W.-H.; Li, G. Moisture assisted perovskite film growth for high performance solar cells. Appl. Phys. Lett. 2014, 105, 183902. [CrossRef]

27. Wang, F.; Ye, Z.; Sarvari, H.; Park, S.M.; Abtahi, A.; Graham, K.; Zhao, Y.; Wang, Y.; Chen, Z.D.; Li, S. Humidity-insensitive fabrication of efficient perovskite solar cells in ambient air. J. Power Sources 2018, 412, 359-365. [CrossRef]

28. Pascoe, A.R.; Meyer, S.; Huang, W.; Li, W.; Benesperi, I.; Duffy, N.W.; Spiccia, L.; Bach, U.; Cheng, Y.-B. Enhancing the Optoelectronic Performance of Perovskite Solar Cells via a Textured $\mathrm{CH}_{3} \mathrm{NH}_{3} \mathrm{PbI}_{3}$ Morphology. Adv. Funct. Mater. 2016, 26, 1278-1285. [CrossRef]

29. Lo, M.-F.; Guan, Z.-Q.; Ng, T.-W.; Chan, C.-Y.; Lee, C.-S. Electronic Structures and Photoconversion Mechanism in Perovskite/Fullerene Heterojunctions. Adv. Funct. Mater. 2014, 25, 1213-1218. [CrossRef]

30. Luo, D.; Yang, W.; Wang, Z.; Sadhanala, A.; Hu, Q.; Su, R.; Shivanna, R.; Trindade, G.F.; Watts, J.F.; Xu, Z.; et al. Enhanced photovoltage for inverted planar heterojunction perovskite solar cells. Science 2018, 360, 1442-1446. [CrossRef] [PubMed]

31. Poglitsch, A.; Weber, D. Dynamic disorder in methylammoniumtrihalogenoplumbates (II) observed by millimeter-wave spectroscopy. J. Chem. Phys. 1987, 87, 6373-6378. [CrossRef]

32. Yang, D.; Yang, R.; Ren, X.; Zhu, X.; Yang, Z.; Li, C.; Liu, S. Hysteresis-Suppressed High-Efficiency Flexible Perovskite Solar Cells Using Solid-State Ionic-Liquids for Effective Electron Transport. Adv. Mater. 2016, 28, 5206-5213. [CrossRef] [PubMed]

33. Bube, R.H. Trap density determination by space-charge-limited currents. J. App. Phys. 1962, 33, 1733-1737. [CrossRef]

34. Dong, Q.; Fang, Y.; Shao, Y.; Mulligan, P.; Qiu, J.; Cao, L.; Huang, J. Electron-hole diffusion lengths $>175 \mu \mathrm{m}$ in solution-grown $\mathrm{CH}_{3} \mathrm{NH}_{3} \mathrm{PbI}_{3}$ single crystals. Science 2015, 347, 967-970. [CrossRef] [PubMed] 